\title{
ANIMAL METAPHORS IN IWAN FALS' SOCIAL CRITICS AND HUMANITY SONGS: ECOLINGUISTICS STUDY
}

\author{
Mutia Mawaddah Rohmah ${ }^{1}$ \\ 1(Andalas University/31mutia@gmail.com) \\ Oktavianus $^{2}$ \\ ${ }^{2}$ (Andalas University/okv_26@yahoo.com) \\ Fajri Usman ${ }^{3}$ \\ 33(Andalas University/usman_fajri@yahoo.com)
}

\begin{abstract}
Language and ecology have the reciprocal relationship in Ecolinguistics perspective. One of the relationship is formed through the metaphorical expressionscontaining the names of fauna(animal metaphors). This study described the animal metaphors found in Iwan Fals' Social Critics and Humanity songs that very famous among Indonesian community. Through Ecolinguistics study, the writer tried to find out how animal as a part of ecosystem can be used to describe human life especially their social and political life through metaphorical frames. This is a descriptive-qualitative research that is conducted by using Ecolinguistics parameters consists of interrelationship, diversity and environment parameters to analyze the interactions between language and ecology. The result of analysis showed that the metaphorical expression formulated and generated from the characteristic of the nature of fauna (animal metaphors) that found in Indonesian environment. The nature used as a source domain was mapped to a target domain referred to human beings with their activities forming a new understanding and enrich vocabulary. The connection between the two domains was recorded in cognitive of the language users at the ideological dimension which is then understood by society at the sociological dimension. The whole meaning formed a strong relationship between language and environment.
\end{abstract}

Keywords:

Metaphor; Biological dimension; Ideological dimension; Sociological dimension

DOI: $10.19105 /$ ojbs.v13i1.2237

\section{A. Introduction}

The topic language and environment is the subject of the new discipline; Ecolinguistics which has been defined as the study of interactions between any given language and its environment. ${ }^{1} \quad$ This study at the beginning of its appearance was named by Haugen as the study of 'language

\footnotetext{
${ }^{1}$ Haugen in Alwin Fill and Peter Mühlhäusler, Ecolinguistics Reader: Language, Ecology and Environment (London: Continuum, 2001).
} 
ecology' as a form of a new paradigm that tried to see the interrelationships between ecology and language. Haugen used the concept of language environment metaphorically in which the environment is understood as a user community of a particular language as one of the language codes they used. ${ }^{2}$ In this case, Haugen sees that there is an analogy between language and environment in the formation of metaphor in the form of 'ecological metaphor' which is present in the midst of society.

Kövecses explained that metaphors are constructed based on a conceptual system which are in turn based on universal embodiment of human experience with the surrounding physical world (environment). ${ }^{3}$ The history of the metaphor 'money is water', for instance, has illustrated how language adapts to new environment condition. ${ }^{4}$ This explanation showed that metaphor as linguistic phenomenon has some relations toward the natural environment of the language users.

As a language device, metaphors involves two domains, they are source domain and target domain. The source domain is more physical related to all entity in our surrounding and the target domain is a more kind of abstract things refers to human being with their all

\footnotetext{
${ }^{2}$ Haugen in Fill and Mühlhäusler.

${ }^{3}$ Zoltán Kövecses, Metaphor in Culture: Universality and Variation (Cambridge: Cambridge University Press, 2005).

${ }^{4}$ Fill and Mühlhäusler, Ecolinguistics Reader, 5.
}

activities. The source domain in this research will focus in the diversity of fauna or we called as animal metaphors. This kind of metaphors used in many situations such as conversation, literature, poem, song and other circumstances to refer human behavior. The conceptual metaphor "Human is Animal" and "Human Behaviour is Animal Behaviour" in Ecolinguistics study is one of the interesting topics. The interactions between "human" and "animal" in animal metaphors are used to find out the interrelationship between ecology and language. Cowards are represented as chickens, lions denote the brave and crowd-followers are sheep refers to some example of conceptual metaphors of 'human as animal'.

In this research, the writer used Iwan Fals' social critics songs found in the YouTube Indo Music Platinum which had been seen as much as 9.477.139 times. They are Surat Buat Wakil Rakyat, Manusia 1/2 Dewa, Bongkar, Siang Seberang Istana, Bung Hatta, Sarjana Muda, Galang Rambu Anarki, Sumbang, Doa Pengobral Dosa, Bangun Putra Putri Pertiwi, Robot Bernyawa, Sore Tugu Pancoran, Generasi Frustrasi, Barang Antik, Guru Oemar Bakri, Belalang Tua, PHK, Serdadu, Tikus-tikus Kantor and Untukmu Negeri. The writer choices this collection of songs because there are so many animal metaphors found in this collection which expressing socio-cultural reality of Indonesian societies. This statement is supported by Lakoff dan Johnson's idea 
that stated metaphors may create realities for us, especially social realities. $^{5}$

In general, there are some reviews of related studies from the prior researchers who also concern about Ecolinguistics as the formal object. They are Mahnaz, Amir and Ardiel. Mahnaz ${ }^{6}$ from Alzahra University, Iran, investigated the relationship between environment and anger metaphors in various cultures. The anger expressions were taken from American English, Chinese, Japanese, Hungarian, Akan, Persian, Tunisian Arabic and Arabic. The result of analysis shows that most of the anger metaphors are motivated by the speaker's physical experience such as increase in skin temperature and blood pressure. Such as in American culture, most of language communities used expression like "Anger is heat". This is in accordance with the analogy when someone is angry, body temperature and blood pressure will increase. This situation is such a consequence of human biological properties.

Amir from Tarbiat Modarres University also conducted an Ecolinguistics analysis. ${ }^{7}$ This paper

${ }^{5}$ George Lakoff and Mark Johnsen, Metaphor We Live By (London: The University of Chicago Press, 2003).

${ }^{6}$ Mahnaz Talebi Dastenaei, "Ecometaphor: The Effect of Ecology and Environment on Shaping Anger Metaphors in Different Cultures," The International Ecolinguistics Association Language \& Ecology (2015): 18.

${ }^{7}$ Amir Ghorbanpour, "Ecolyrics in Pop Music: A Review of Two Nature Songs," The International analyses the underlying stories that lie behind the lyrics and how they model the natural world. There are two songs chosen entitled "We Kill the World" and "Jonny Wanna Live". The interactions between song lyrics and their environment enrich the new term in Ecolinguistics study, it called 'ecolyric'. The results of the study revealed that environmental songs have something they want to convey more than what the hearer heard. Through the lyrics, the songs represent a binary division between humans and the rest of the world. He illustrated that everything does not always have to be related to humans, but something that is outside of humans also has an important role. The song entitled "We Kill the World" is thematically written to critic the destruction of 'environment' carried out by humans. The use of metaphors and appraisal patterns try to explain the importance of nature or environment as the home of all living things. The second song titled "Jonny Wanna Live" described a form of animals' resistance to human cruelty. The song brings the existence of animals to become the focus of human attention by using personification, naming and activation.

A similar study was also conducted by Ardiel $^{8}$ She conducted the use of

Ecolinguistics Association Language \& Ecology (2016): 10.

${ }^{8}$ Vonny Ardiel, "Leksikon Dalam Tradisi Maambiak Ari Bacocok Tanam Padi Di Nagari Jaho Kabupaten Tanah Datar: Tinjauan Ekolinguistik" (Unpublished Thesis, Andalas University, 2017). 
lexicons in Maambiak Ari Bacocok Tanam Padi in Nagari Jaho, Tanah Datar, West Sumatera. She also used theory of Dialectical Social Praxis to analyze the interrelationship between the rice cultivation's lexicons with environment. This research found that the procession of rice cultivations was interpreted as a form of hope for obtaining blessing (ideological dimension), rice is considered to be the main symbol of family economy (sociological dimension) and the form of naming the lexicons in Tradisi Maambiak Ari is based on plant properties constitute as a part of biological dimension.

Like some related studies above, this research was also done under the Ecolinguistics perspective. Ecolinguistics consider that language is a product of human activities and a part of social praxis. $^{9}$ It means the investigation of language at the same time is the investigation of human's social praxis. Døør and Jørgen formulated linguistic theory in relation to dialectical theory of the social praxis. The theory is known as the three dimensionality of the social praxis.

Døør and Jørgen explained that Ecolinguistics is a study that investigates mutual relationship between language with ideological dimension, sociological dimension and biological dimension of

\footnotetext{
${ }^{9}$ Jørge Døør and Jørgen Chr Bang, "Language, Ecology \& Truth - Dialogue \& Dialectics," Sprogteori IX, 1995, http://www.jcbang.dk /main/ecolinguistics/Six.pdf.
}

language. The ideological dimension is about our individual or collective mental, cognitive, ideological and psychic systems. The sociological dimension is about the ways we organize our interrelations in order to maintain a collectivity of individuals, whether these individuals love each other, know each other, or are strangers to each other.

The biological dimension is about our biological collectivity and our coexistence with other species (animals, plans, soil, oceans, microorganism, macro organisms, etc.).$^{10}$ The following figure will describe the interrelation between the three dimensions adapting to Bang and Døør as follow:

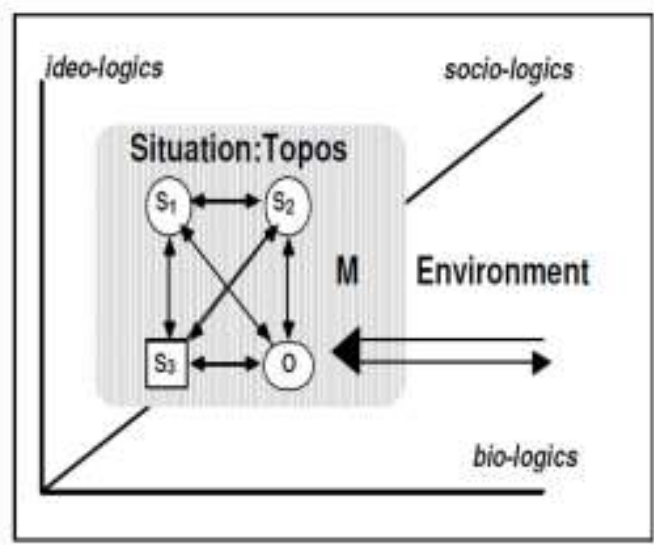

Figure 1: Dialectical Social Praxis (Source: Bang \& Door, 1995 in Bundsgaard and Sune, 2000: 10)

Based on the explanation above, this study aims to describe the interrelationship between metaphors that provide the natural environment of fauna or called as animal metaphors as a source domain and human's life with all

\footnotetext{
${ }^{10}$ Jeppe Bundsgaard and Sune Steffensen, "The Dialectics of Ecological Morphology," in Dialectical Ecolinguistics (Odense: Odense University, 2000).
} 
of his characters as the target domain. The discussion is directed to analyzing interrelationship of the natural environment that motivated the formation of metaphors using three dimensionality of the social praxis; they are ideological, sociological and biological dimensions. Three dimensions above will describe the interactions between language and environment and all at one reflects the social and political situation in Indonesia through the lyrics.

\section{B. Method}

This research was descriptivequalitative approach. Source of data were obtained from Iwan Fals' song lyrics. Song, like novel and other literary works, also offers a wider range of social issues through its lyrics. ${ }^{11}$ Because of this reason, the researcher chooses Iwan Fals' social critic's songs to convey Indonesian social life through the use metaphorical expressions especially 'animal metaphors'. Those songs download from YouTube on the Indo Music Platinum page which was watched as many as 9.164.777 times.

In conducting the research, three research steps were conducted. The first step is collecting the data. The researcher uses observational method ${ }^{12}$ in which the researcher listens to the use

\footnotetext{
${ }^{11}$ Abd Ghofur, "Reading Our Social Words: Utilizing Novels in Teaching Sociology Courses" 6 , no. 1 (2012): 53-66.

${ }^{12}$ Sudaryanto, Metode Dan Aneka Teknik Analisis Bahasa: PengantarPenelitian Wahana Kebudayaan Secara Linguistis (Yogyakarta: Duta Wacana University Press, 2018).
}

of language in Iwan Fals' lyrics contains animal metaphors. This method uses with non-participant observational technique because the researcher in obtaining the data is not being involved in the data itself. The researcher also uses note-taking technique to make the analysis easier.

The second step is analyzing the data. The combination of distributional method and referential identity method were used. The distributional method is used to analysis the nature of animal metaphor through their lexical meaning in dictionary. Then, the referential identity method is applied to describe the situational context which motivated the use of animal metaphors in Iwan Fals' lyrics. The context can arrive from social or political context.

The third step is presenting result of analysis. The researcher uses ordinary words or natural language (nonformal method). In some situation, this study also uses symbol (formal method). Furthermore, the researcher also uses tables to list the animal metaphors itself.

\section{Results}

The animal metaphors that found in Iwan Fals' song are around 10 items. They are as followed:

\begin{tabular}{|l|l|l|}
\hline No. & \multicolumn{1}{|c|}{$\begin{array}{c}\text { Animal } \\
\text { Metaphors }\end{array}$} & \multicolumn{1}{|c|}{ Gloss } \\
\hline 1. & Kambing Hitam & Goat \\
\hline 2. & Nyamuk Nakal & Mosquito \\
\hline 3. & Cengkeramanmu & Garuda \\
\hline 4. & Kutu & Fleas \\
\hline
\end{tabular}




\begin{tabular}{|l|l|l|}
\hline 5. & Sapi Perah & Cow \\
\hline 6. & Kutu Jalanan & Fleas \\
\hline 7. & Belalang Tua & Grasshopper \\
\hline 8. & Tikus & Mice \\
\hline 9. & Otak Udang & Shrimp \\
\hline 10. & Kucing & Cat \\
\hline
\end{tabular}

\section{Data 1}

Lalu sibuk mencari kambing hitam ${ }^{13}$

"They are busy seeking black goat"

In the piece of the song above, there is an animal metaphor kambing hitam, black goat. The central element of the noun phrase is 'goat'. This animal is a medium sized ruminant animal. According to some studies, goats are the earliest animals raised by humans. Studies of DNA evidence show that goats have lived with humans since 10.000 years ago. ${ }^{14}$ Based on these descriptions, it was found a reality that goats had lived very close to humans. Therefore, this animal is made as one of the source domains of metaphor in the form of black goat.

The term black goat or familiarly known as scapegoat according to history was first used as a sacrificial animal in the Yom Kippur ceremony. Based on the Hebrew Scriptures, there were two male goat brought to the temple in Yerusalem on the day of the Yom Kippur ceremony

13 Iwan Fals, Sumbang, Mp3 (Musica Studio, 1983).

${ }^{14}$ Aron Batubara et al., "Keragaman Genetik DNA Y-Kromosom Pada Enam Rumpun Kambing Lokal Indonesia," in Seminar Nasional Teknologi Peternakan Dan Veteriner, 2013. as a part of holy worship (Enders, n.d; MJL, 2002). The High Priest released the lottery for the two goats. One of them was dedicated as a blood sacrifice and the other was used as a sacrifice for confession. The High Priest put his hand on the head of the goat and then confessed the sins of the Israelites. Besides the Israelites, Christians also have a story about the black goat, which are used as symbols for the recognition of human sin. Based on the history, a black goat becomes the source of metaphor for human who interpreted as 'someone who is blamed'.

According to the Kamus Besar Bahasa Indonesia, ${ }^{15}$ black goat is interpreted as a person who is blamed for the wrongdoings, mistakes or faults of others. Based on that meaning, the goat as the symbol for recognition of human sin is used as source domain of metaphor mapped to human kind as the target domains in the form of 'someone who is blamed for the wrongdoings of others'.

The meaning of black goat as the person being blamed is also inseparable from the following context:

Maling teriak maling sembunyi di balik dinding

Pengecut lari terkencing-kencing

Tikam dari belakang lawan lengah diterjang

Lalu sibuk mencari kambing hitam ${ }^{16}$

\footnotetext{
${ }^{15}$ Badan Bahasa Depdiknas, Kamus Besar Bahasa Indonesia, 4th ed. (Jakarta: Gramedia, 2014).

16 Iwan Fals, Sumbang, Mp3 (Musica Studio, 1983).
} 
"Thief cried out thief and hiding behind the wall

Coward run and run

Stabbed from backside, the opponent will be kicked

They are busy seeking black goat"

The treatment received by goat which is used as 'sacrificial confession' (biological dimension) makes this animal used as a source inspiration for scapegoat metaphor. The similarity of treatment received by goat is recorded verbally and non-verbally in Indonesian society in ideological dimension. In the social life, humans scapegoat are interpreted as people who are blamed for an actions that they are never done. In our political life, many politicians blamed others for what they have done.

\section{Data 2}

\section{Berteman nyamuk nakal ${ }^{17}$}

"Befriending with naughty mosquitoes"

Based on the data (2) above, there is an animal metaphor nyamuk nakal. Ecologically, mosquitoes are insects that cause many problems for humans. Mosquitoes are vectors of several types of dangerous and deadly diseases for human such as dengue, malaria, filariasis and chikungunya. ${ }^{18}$ The breeding of mosquito is so fast, a female mosquito can release as many

\footnotetext{
${ }^{17}$ Iwan Fals, Doa Pengobral Dosa, Mp3 (Musica Studio, 1981)

${ }^{18}$ Alvine Budiman, "Sistem Pakar Diagnosis Penyakit Akibat Gigitan Nyamuk Disertai Animasinya" (Unpublished Minithesis, Universitas Muhammadiyah Surakarta, 2014).
}

as 100 eggs. The main breeding sites are places filled with water adjacent to the houses. The life of mosquitoes very close to human causes mosquito uses in various situations of speech such as in animal metaphor nyamuk nakal.

The presence of mosquitoes as a source of disease was mapped to humans as a result of cognitive mental understanding of the speech community at the ideological level. This mapping produces animal metaphor nyamuk nakal as commercial sex workers (in Indonesia called as PSK, Pekerja Seks Komersial). Like nyamuk as source of disease, PSK is also a source of community disease. ${ }^{19}$ This understanding was born on the basis of the similarity between two entities as a source of disease. Animal metaphor nyamuk nakal interpreted as a prostitute is inseparable from the following context:

Di sudut dekat gerbong yang tak terpakai

Perempuan bermake up tebal

Dengan rokok ditangan

Menunggu tamunya datang...

Terpisah dari ramai

Berteman nyamuk nakal

Dan segumpal harapan

Kapankan datang tuan berkantong tebal? ${ }^{20}$

"In the corner near the unused wagon Women wearing thick make up

\footnotetext{
${ }^{19}$ Siti Munawaroh, "Pekerja Seks Komersial (PSK) di Wilayah Prambanan, Kabupaten Klaten, Jawa Tengah," Dimensia: Jurnal Kajian Sosiologi 4, no. 2 (2010): 69-82.

${ }^{20}$ Iwan Fals, Doa Pengobral Dosa, Mp3 (Musica Studio, 1981)
} 
With cigarettes in the hand

Waiting for her guest to come ...

Separated from crowd

Befriending with naughty mosquitoes

And a wisp of hope

When does Mr big pocket come?"

An understanding of the biological characteristics of mosquitoes that cause various diseases from the community (biological dimension) is recorded in the cognitive speech community at the level of the ideological dimension. The biological character of this animal as a source of disease mapped to PSK, because of their presence also causing a moral disease for society. At the social level, working as a prostitute is considered as taboo and also violate moral values in social and religious life (sociological dimension). Thought biological, ideological and sociological dimension, animal metaphor nyamuk nakal is formed in some utterances.

\section{Data 3}

Bersatu dalam cengkeramanmư ${ }^{21}$ "Unite in your grip"

In the piece of the song above, there is an animal metaphor cengkeramanmu. This grip belong to the eagle, burung Garuda; the symbol of the NKRI. The existence of the bird as a symbol of the state is certainly questioned by many parties. Various questions arise related to whether the

${ }^{21}$ Iwan Fals, Bangunlah Putra Putri Pertiwi, Mp3 (Musica Studio, 1981). bird is only in the form of mythology or an animal that lives in the wild. The initial design of Garuda Pancasila made by Sultan Hamid II shows the traditional form of Garuda with a human body. Garuda with human hands and shoulders holding the shield is considered too mythological like the description of Garuda in puppet stories on Java. However, after revising, Sultan Hamid II re-proposed the new design in which Garuda Pancasila looked like Elang-Rajawali. The form of ElangRajawali as the embodiment of Garuda Pancasila stated in Article 46 of Law number 24 yeas 2008 concerning Flags, Language, National Symbols and National Anthems which in its explanation states: what is meant by Garuda Pancasila is a symbol of eagle that have been known through ancient mythology that resembling Hawk Eagle. $^{22}$

Based on the description above, it can be seen that burung Garuda lived very close to societies through the story of puppetry (the mighty bird which is used as the ride of Lord Vishnu). Garuda is described having a golden body, white face, red wings but its body like human. Ecologically, eagle is a bird of prey. ${ }^{23}$ As a bird of prey, eagles have a strong

\footnotetext{
22. Turiman, "Menelusuri 'Jejak' Lambang Negara Republik Indonesia berdasarkan Analisis Sejarah Hukum," Jurnal Hukum \& Pembangunan 44, no. 1 (February 26, 2014): 121-69, https://doi.org/10.21143/jhp.vol44.no1.18.

${ }^{23}$ Surya Kusuma Wijaya, "Masalah Infestasi Ektoparasit Pada Beberapa Jenis Burung Elang Di Habitat Eks-Situ" (Unpublished Minithesis, Institut Pertanian Bogor, 2008).
} 
grasp to catch their prey with a high success rate. As far as the birds are concerned, the grip is used as the source domain of animal metaphor cengkramanmu. The depiction is formed on the basis of human scrutiny of the might possessed by eagle in the realization of Garuda Pancasila which can unite the Republic of Indonesia under the motto Bhinneka Tunggal Ika. The meaning of eagle's grip as an embodiment of the power of Garuda Pancasila unites NKRI is inseparable from this lyric:

Sinar matamu tajam namun ragu
Kokoh sayapmu semua tahu
Tegap tubuhmu tak kan tergoyahkan
Kuat jarimu kala mencengkeram
Bermacam suku yang berbeda
Bersatu dalam cengkramanmu²
"Your eyes are sharp but doubtful
Sturdy your wings, all know
Strapping your body, will not be
deterred frength of your finger when
The strength
gripping
Various different tribes
United in your grip"

An understanding of the biological character of eagle at the level of the biological dimension is related to the strength of grip for capturing their prey recorded in the cognitive speech community at the level of the ideological dimension. The strength of eagle's grip is described as the strength of the grip of Garuda Pancasila in maintaining the unity of Indonesia. This character makes

${ }^{24}$ Iwan Fals, Bangunlah Putra Putri Pertiwi, Mp3 (Musica Studio, 1981). the eagle used as a source domain in the formation of animal metaphor cengkramanmu in the realization of the grip of Garuda Pancasila. In the life of the nation, Garuda Pancasila holds the philosophical value of the Indonesian who is able to unite the state that comes from various tribes, cultures, customs and languages (sociological dimension).

\section{Data 4}

Singkirkan kutu-kutu di sayapmu ${ }^{25}$

"Get rid of fleas on your wings"

In the data (4), there is an animal metaphor kutu-kutu. This metaphor is a form of reduplication of the word kutu. This animal is a wingless parasitic insect that sucks human and animal blood. In humans, these animals are known as head fleas (pediculus humanus capitis). Although head lice do not cause serious health problems, their presence can be very disturbing. It happens because of scratching. The feeling of scratching arises because these small insects suck human blood through the scalp. Those animals do it to obtain food sources. Pediculus humanus capitis cannot live without human blood within 15-20 hours. ${ }^{26}$ Its presence so close to human life, raises a metaphor that utilized the

\footnotetext{
${ }^{25}$ Iwan Fals, Bangunlah Putra Putri Pertiwi, Mp3 (Musica Studio, 1981).

${ }^{26}$ Azizul Hakim and Pratiwi Rimadani, "Uji Efektifitas Sampo Dari Minyak Mimba Sebagai Antikutu Di Rambut," Farmaka 16, no. 1 (2018): $1-14$.
} 
nature and character possessed by this animal as a source of inspiration.

The character of fleas as parasitic in human head causes Indonesian speech society interpreting the presence of these animals as a 'disturber' in human life. The metaphor kutu used as source domain is meant to someone who lives asa disturber. This meaning was born based on the similarity of the characters possessed by the two entities. The meaning of fleas as a disturber is also inseparable from the following lyrics:

Terbanglah garudaku

Singkirkan kutu-kutu di sayapmu oh... Berkibarlah benderaku

Singkirkan benalu di tiangmu ${ }^{27}$

"Fly my Garuda

Get rid of the fleas on your wings oh.. My flag fluttered

Get rid of the parasite on your pole"

Through the description above, it was found that there is the similarity between the fleas considered as parasites (biological dimension) with human who possessed the character of adisturber. The similarity of the nature possessed by fleas and adisturber are recorded in the mental cognitive speech society ay the ideological dimension. In the social context, adisturber is considered as the person who always makes riots in the lives of others.

${ }^{27}$ Iwan Fals, Bangunlah Putra Putri Pertiwi, Mp3 (Musica Studio, 1981).

\section{Data 5}

Sapi perah di zaman modern ${ }^{28}$

"Dairy cows in modern times"

In the piece of the song above, there is an animal metaphor sapi perah, dairy cattle or dairy cows. Ecologically, cows are raised by humans to be used for milk, meat and energy. Especially for dairy cows, these animals are lined up to produce milk only. ${ }^{29}$ As a milk producer, the presence of fairy cows is one of the main commodities of the livestock subsector whose his presence can help meet the needs of animal protein of the Indonesian people. Behind the efforts to fulfill the needs of milk production, there was exploitation, brutal torture and cruel treatment of the dairy farm. On average, a cow can provide about 10 liters of milk per day. ${ }^{30}$

To increase the amount of production, breeders deliberately fertilize cows not for the purpose of breeding cows, but to increase the amount of milk produced by the cows. On average each cow will provide about 24.5 liters of milk per day, many times more than the natural amount produced by cows when they not breastfeeding their children. Moreover the number of milk can reach

\footnotetext{
${ }^{28}$ Iwan Fals, Robot Bernyawa, Mp3 (Musica Studio, 1991).

${ }^{29}$ Badan Bahasa Depdiknas, Kamus Besar Bahasa Indonesia.

${ }^{30}$ Muhammad Idris, "Peternak Sapi Perah: Kalau Hitungan Akuntasi, Kami Rugi Terus Jual Susu," accessed May 6, 2019, https://finance.detik.com/berita-ekonomi-bisnis/d3345969/peternak-sapi-perah-kalau-hitunganakuntasi-kami-rugi-terus-jual-susu.
} 
40 liters per day. ${ }^{31}$ This treatment is considered as a form of exploitation of cows which causes physical and mental suffering for these animals. This exploitation is likened to the treatment of employers who exploit 'energy' from laborers. Therefore, animal metaphor sapi perah emerges as a source domain that is mapped for human as a target domain refers to people who are squeezed his energy by others. If referring to the piece of the lyrics below, the person refers to 'labor worker':

Robot bernyawa teruslah bekerja Sapi perahan di zaman modern Mulut dikunci tak boleh bicara Di depan pabrik minta keadilan ${ }^{32}$

"Animate robot keeps working Dairy cows in modern times The mouth locked, can't talk In front of the factory asking for justice"

Based on the sensory experience of humans who see how breeders treat their dairy cows (biological dimension) emerges the embodiment of animal metaphor sapi perah. This embodiment is recorded in the cognitive speech community at the ideological dimension. From this comprehension, a dairy cow

\footnotetext{
${ }^{31}$ Asmanih, "Fakta Mengejutkan Di Balik Pemenuhan Kebutuhan Susu, Seekor Sapi Dipaksa Kawin Dan Hampir 150.000 Anak Sapi Terbunuh Tiap Tahun," Erabaru (blog), December 28, 2017, http://m.erabaru.net/2017/12/28/faktamengejutkan-di-balik-pemenuhan-kebutuhansusu-seekor-sapi-dipaksa-kawin-dan-hampir-150000-anak-sapi-terbunuh-tiap-tahun/.

32 Iwan Fals, Robot Bernyawa, Mp3 (Musica Studio, 1991).
}

was formed based on the understanding as humans who used their energy continuously by others like laborers. Through the use of this metaphor, Iwan Fals wants to convey the social reality related to the unfair treatment faced by our laborers in Indonesia (sociological dimension).

\section{Data 6}

Bagai kutu jalanan di tengah-tengah kota metropolitan ${ }^{33}$

"Like street lice in the middle of a metropolitan city"

Based on the lyric above, there is animal metaphor kutu jalanan. Such the description before, fleas like to gnaw at human and animal hair and suck their blood, causes Indonesian speech community to interpret the presence of these animals as 'people who like do something'. The noun phrase kutu jalanan; street fleas, composes the meaning that refers to 'people who like walk round the streets; driver. The meaning was born based on the similarity of character possessed by kutu jalanan and oplet driver. The meaning of street fleas as the manifestation of human who likes to go back and forth on the streets is also inseparable from the following lyrics:

\footnotetext{
${ }^{33}$ Iwan Fals, Barang Antik, Mp3 (Musica Studio, 1984).
} 
Hai oplet tua dengan bapak supir tua Cari penumpang di pinggiran ibu kota Sainganmu mikrolet, bajaj dan bis kota

Kini kau tersingkirkan oleh mereka ${ }^{34}$

"Hi old oplet with the old driver

Look for passengers on the outskirts of the capital city

Your rivals are mikrolet, bajaj and city buses

Now you get rid of them"

Understanding of the biological character of fleas who like to gnaw at human hair and suck their blood (biological dimension) was recorded in people's cognitive forming animal metaphor kutu jalanan (ideological dimension). Fleas as a source domain on kutu jalanan mapped to target domain refers to someone who like go on the streets. Based on the piece of the lyrics above, the person refers to the oplet driver in a metropolitan city who moves back and forth looking for passengers. In the social context, the presence of oplet drivers in metropolitan city caused many problems, especially causing congestion everywhere. On the other hand, they do this effort to provide a decent livelihood for their families (sociological dimension). It looks like a dramatic social life in Indonesia.

\section{Data 7}

Belalang tua di ujung daun ${ }^{35}$

"Old grasshopper on the tip of leaf"

34 Iwan Fals, Barang Antik, Mp3 (Musica Studio, 1984).

${ }^{35}$ Iwan Fals, Belalang Tua, Mp3 (Musica Studio,2002).
In datum (7), the use of the animal metaphor belalang tua is indicated. This metaphor consists of the word grasshopper as basic word. In certain population, these animals can become plant pests that are very disturbing to farmers. As a plant eater, grasshoppers can spend leaves up to 16 times from their body weight. ${ }^{36}$ In Indonesia, kind of Locustae in form of belalang kembara (Locustae Migratoriamanilensis L) can damage the productivity of the plants. Therefore, in certain types of grasshopper can be a destroyer of plants. Based on this description, it was found a reality that grasshoppers had lived very close to humans being.

The nature of grasshoppers who can eat as much as 16 times from weight of their body puts this animal as a source domain to describe 'greedy humans' (target domain). The meaning was born base on the similarity of the character of the two entities. The meaning old grasshopper as an embodiment of greedy humans is inseparable from this lyric as follow:

Kisah belalang tua yang berhenti mengunyah

Sebab kubilang kamu serakah

Belalang tua di ujung daun

Dengan tenang meninggalkan harta karun $^{37}$

\footnotetext{
36"Grasshopper - Facts, Diet \& Habitat Information," accessed May 7, 2019, https://animalcorner.co.uk/animals/grasshopper/. 37 Iwan Fals, Belalang Tua, Mp3 (Musica Studio,2002).
} 
"The story of an old grasshopper who stopped chewing

Because I said you were greedy

Old grasshopper on the tip of leaf Calmly, leaving the treasure"

The piece of lyrics above contains Iwan Fals' concern for the social phenomena that have occurred in Indonesia. The song entitled Belalang Tua tells about the greedy of someone who is old and still doesn't feel full of the 'power' he has. Based on the background of the time, this people referred to the greedy leader who did not want to give up for his power and position.

An understanding of the biological character of grasshoppers that have the ability to eat 16 times from the total of his weight is recorded in the cognitive speech society at the ideological dimension. Through this embodiment, metaphor belalang tua was formed based on his voracity and mapped to greedy humans especially greedy leaders. In social context, the greedy leader is very disliked by his people, especially if during his leadership did not bring significance changes to Indonesian (sociological dimension).

\section{Data 8}

Tikus-tikus tak kenal kenyang ${ }^{38}$ “Mice don't know gorged"

In the piece of the song above, there is an animal metaphor tikus-tikus as

38 Iwan Fals, Tikus-tikus Kantor, Mp3 (Musica Studio, 1986). a form of reduplication of tikus; mouse. In Indonesia, there are at least three types of mice that live around the human environment. They are tikus got (Rattus Norvegicus), tikus rumah or tikus atap (Rattus Rattus) and mencit rumah (Musmusculus). ${ }^{39}$ Ecologically, mouse belongs to disgusting animals. One of them is rat. These animals are jet black, big in size around 400-600 grams, live in drains, bins and other dirty places. This big rats become pests around the human environment because of they inhabit in dirty places outside the house.

The lives of rats which are very close to humans cause some human behavior to be compared to the rat's behavior. The behavior of rats who like to live in dirty environments is fed like corruptor behavior who likes to do dirty or despicable work such as misuse money for personal gain. The meaning of rats who like to live in dirty environments is supported by lyrics below:

Kisah usang tikus-tikus kantor
Yang suka berenang di sungai yang
kotor
Kisah usang tikus-tikus berdasi
Yang suka ingkar janji lalu sembunyi ${ }^{40}$
"The old story of the office mice
Who likes to swim in dirty rivers
The old story of mice with tie
Those who like broken promises then
hide"

\footnotetext{
${ }^{39} \mathrm{M}$ Zaid Wahyudi, "Tikus-tikus di Sekitar Kita Halaman all," KOMPAS.com, accessed May 7, 2019, https://regional.kompas.com/read/2013/04/04/040 44145/tikus-tikus.di.sekitar.kita.

40 Iwan Fals, Tikus-tikus Kantor, Mp3 (Musica Studio, 1986).
} 
The behavior of rats that like to live in dirty environments (biological dimension) is identical to corruptor behavior that likes to do dirty work. In the social life, corruptors are known as human who like to abuse money to satisfy their desires (ideological dimension). Rats that like to occupy the waterways can bring disease to humans, as well as corruptor actions that steal people's money or nation's money understood socially as the cause of financial loss for humans (sociological dimension).

\section{Data 9}

Otak tikus memang bukan otak udang $^{41}$

"a mouse brain is not a shrimp brain"

In datum (9), the use of the animal metaphor otak udang is indicated. The basic form of this metaphor is udang; shrimp. Animals that belong to Crustaceans' orderhave a united anatomical structure between the head and abdomen which are fused together. This unite structure becomes an inspiration the metaphor shrimp brain which is used as a symbol of 'stupidity'. It happens because shrimp don't have a bulkhead between the head and the stomach. This condition indicating the shrimp brain itself is directly related to the digestive system that produces feces. These feces are interpreted as

${ }^{41}$ Iwan Fals, Tikus-tikus Kantor. human's thinking that is not clear; stupid. $^{42}$

There is also another assumption that states shrimp don't have a brain. Actually, this assumption is wrong. Shrimp and other types of animals belonging to the crustaceans have brains but do not use it as the center of control like human being. The shrimp brain system known as the rope ladder system is a collection of ganglia or cerebellum located along the body segment of the shrimp. These sensors convey information about the surrounding conditions such as vibration, chemical elements and also slightest movement of water.

The similarity between shrimp brain and people creates the using shrimp as the source domain of animal metaphor otak udang. The meaning of the shrimp brain as an embodiment of stupidity is also inseparable from the lyrics below:

Tikus-tikus tak kenal kenyang
Rakus, rakus bukan kepalang
Otak tikus memang bukan otak udang
Kucing datang tikus menghilang ${ }^{43}$
"Mice don't know gorged
Very greedy unbelievable
A mouse brain is not a shrimp brain
The cat comes, the mouse
disappears"

\footnotetext{
${ }^{42}$ St. Humairoh, "Otak Udang dan Analogi Kebodohan," Kabar Kusam (blog), March 22, 2018 ,

https://creativeliteraci.blogspot.com/2018/03/otakudang-dan-analogi-kebodohan.html.

${ }^{43}$ Iwan Fals, Tikus-tikus Kantor.
} 
Through the piece of lyrics above, Iwan Fals wants to convey a real situation regarding the ingenuity of rats that can fool cats and even be able to shake the cat's belief in receiving a piece of bread. This analogy illustrates the reality of Indonesian law system that is so weak such as law enforcement officers cannot resolve the corruption practices. It happens because the law officers are easily fooled by corruptors.

The descriptive anatomy of shrimp brain united with the digestive system (biological dimension) with a comparison of human who thing using their stomach are mentally recorded in the speech community at the ideological dimension. Based on the song's context, the person refers to the law officers in Indonesia who are considered to be less intelligent because they are easily fooled by corruptors who more clever and tricky (sociological dimension).

\section{Data 10}

Kucing datang tikus menghilang ${ }^{44}$

"The cat comes, the mouse disappears"

In the piece of the song above, there is an animal metaphor kucing. As pets, cat has mingled with human life since at least $9.500 \mathrm{BC}$. In fact, ancient Egyptians from $4.500 \mathrm{BC}$ have used cat to hunt mice or other rodents from barns

44 Iwan Fals, Tikus-tikus Kantor, Mp3 (Musica Studio, 1986). that store their crops. ${ }^{45}$ At present, cat is one of the most popular pets in the world. In Indonesian, most people keep cats in their homes to maintain and control the breeding of rodents, especially mice. They choice cat because naturally cat born as a hunting animal. Cat behavior as one of the hunting animals is likened to the law officers who also hunt down criminals. Based on this similarity, cat in this lyric was interpreted as a law enforcement officer. The meaning of the cat as an embodiment of law enforcement officers is also inseparable from the lyrics below:

Kucing-kucing yang kerjanya molor
Tak ingat tikus kantor datang
menteror
Cerdik, licik, tikus bertingkah tengik
Mungkin karena sang kucing pura-
pura mendelik ${ }^{46}$
"Cats like to sleep
Don't remember mice come terrorizing
Clever, cunning. Mice act rancid
Maybe because the cat pretended to
be glaring"

Cat's natural lifestyle as carnivore that hunts mice (biological dimension) is identical to the duty of law enforcement officer as one of the governing bodies for maintaining peacefulness and public order. This similarity is understood through the sensory experience of society (bodily experience) which is

\footnotetext{
${ }^{45}$ John Pickrell, "Oldest Known Pet Cat? 9,500Year-Old Burial Found on Cyprus," April 8, 2004, https://www.nationalgeographic.com/animals/200 4/04/oldest-known-pet-cat-9500-year-old-burialfound-on-cyprus/.

${ }^{46}$ Iwan Fals, Tikus-tikus Kantor.
} 
recorder verbally and non-verbally in the mental cognitive speech society (ideological dimension). Based on this experience, we know that the low officers having the duty to uphold law and justice (sociological dimension). In this context, the low officers break their duty to protect the Indonesian peacefulness.

\section{Conclusion}

From this research can be drawn an inference that the animal metaphor being used in Iwan Fals' song are structured based on the interrelation of animals' biological characters and humans being. This interrelation is formed by interaction of two models; a source and a target domain. The source domains are formulated from the characteristics of the nature of fauna that grow in sorroundings of Indonesian speech communities. In other hand, the target domain refers to human and their aspect of life. The interelationship between two domains generated 'ecometaphors'in theform of animal metaphors.

The interrelationship between the two domains is formed based on the result of human's understanding in biological dimension, ideological dimension and sociological dimension. They are called the three dimensionality of social praxis. The nature of animal is understood in biological dimension formed the animal metaphor. This forms is built based on the mental cognitive understanding of the Indonesian speech community who see the similarities between the two domains. These similarities then used as a parameter in relation to understand the social live at the level of sociological dimensions. These dimensions construct the strong relationship between language and environment in ecolinguistics study.

\section{References}

Ardiel, Vonny. "Leksikon Dalam Tradisi Maambiak Ari Bacocok Tanam Padi Di Nagari Jaho Kabupaten Tanah Datar: Tinjauan Ekolinguistik." Unpublished Thesis, Andalas University, 2017.

Asmanih. "Fakta Mengejutkan Di Balik Pemenuhan Kebutuhan Susu, Seekor Sapi Dipaksa Kawin Dan Hampir 150.000 Anak Sapi Terbunuh Tiap Tahun." Erabaru (blog), December 28, 2017. http://m.erabaru.net/2017/12/28/f akta-mengejutkan-di-balikpemenuhan-kebutuhan-sususeekor-sapi-dipaksa-kawin-danhampir-150-000-anak-sapiterbunuh-tiap-tahun/.

Badan Bahasa Depdiknas. Kamus Besar Bahasa Indonesia. 4th ed. Jakarta: Gramedia, 2014.

Batubara, Aron, Ronny Rachman Noor, Achmad Farajallah, and Bess Tiesnamurti. "Keragaman Genetik DNA Y-Kromosom Pada Enam Rumpun Kambing Lokal Indonesia." In Seminar Nasional Teknologi Peternakan Dan Veteriner, 2013. 
Budiman, Alvine. "Sistem Pakar Diagnosis Penyakit Akibat Gigitan Nyamuk Disertai Animasinya." Unpublished Minithesis, Universitas Muhammadiyah Surakarta, 2014.

Bundsgaard, Jeppe, and Sune Steffensen. "The Dialectics of Ecological Morphology." In Dialectical Ecolinguistics. Odense: Odense University, 2000.

Dastenaei, Mahnaz Talebi. "Ecometaphor: The Effect of Ecology and Environment on Shaping Anger Metaphors in Different Cultures." The International Ecolinguistics Association Language \& Ecology (2015): 18.

Døør, Jørge, and Jørgen Chr Bang. "Language, Ecology \& Truth Dialogue \& Dialectics." Sprogteori IX, 1995. http://www.jcbang.dk /main/ecolinguistics/Six.pdf.

Fals, Iwan. Sumbang. Mp3. Musica Studio, 1983.

Fill, Alwin, and Peter Mühlhäusler. Ecolinguistics Reader: Language, Ecology and Environment. London: Continuum, 2001.

Ghofur, Abd. "Reading Our Social Words: Utilizing Novels in Teaching Sociology Courses" 6, no. 1 (2012): 53-66.

Ghorbanpour, Amir. "Ecolyrics in Pop Music: A Review of Two Nature Songs." The International
Ecolinguistics Association

Language \& Ecology (2016): 10.

"Grasshopper - Facts, Diet \& Habitat Information." Accessed May 7, 2019.

https://animalcorner.co.uk/animal s/grasshopper/.

Hakim, Azizul, and Pratiwi Rimadani. "Uji Efektifitas Sampo Dari Minyak Mimba Sebagai Antikutu Di Rambut." Farmaka 16, no. 1 (2018): 1-14.

Humairoh, St. "Otak Udang Dan Analogi Kebodohan." KABAR KUSAM (blog), March 22, 2018. https://creativeliteraci.blogspot.co m/2018/03/otak-udang-dananalogi-kebodohan.html.

Idris, Muhammad. "Peternak Sapi Perah: Kalau Hitungan Akuntasi, Kami Rugi Terus Jual Susu." Accessed May 6, 2019. https://finance.detik.com/beritaekonomi-bisnis/d3345969/peternak-sapi-perahkalau-hitungan-akuntasi-kamirugi-terus-jual-susu.

Kövecses, Zoltán. Metaphor in Culture: Universality and Variation. Cambridge: Cambridge University Press, 2005.

Lakoff, George, and Mark Johnsen. Metaphor We Live By. London: The University of Chicago Press, 2003.

Munawaroh, Siti. "Pekerja Seks Komersial (PSK) di Wilayah Prambanan, Kabupaten Klaten, Jawa Tengah." Dimensia: Jurnal Kajian Sosiologi 4, no. 2 (2010): 69-82. 
Pickrell, John. "Oldest Known Pet Cat?

9,500-Year-Old Burial Found on Cyprus," April 8, 2004. https://www.nationalgeographic.c om/animals/2004/04/oldestknown-pet-cat-9500-year-oldburial-found-on-cyprus/.

Sudaryanto. Metode Dan Aneka Teknik Analisis Bahasa:

PengantarPenelitian Wahana Kebudayaan Secara Linguistis. Yogyakarta: Duta Wacana University Press, 2018.

Turiman, -. “Menelusuri 'Jejak' Lambang Negara Republik Indonesia berdasarkan Analisis Sejarah Hukum." Jurnal Hukum \& Pembangunan 44, no. 1 (February 26, 2014): 121-69. https://doi.org/10.21143/jhp.vol44 .no1.18.

Wahyudi, M Zaid. "Tikus-tikus di Sekitar Kita Halaman all." KOMPAS.com. Accessed May 7, 2019.

https://regional.kompas.com/read /2013/04/04/04044145/tikustikus.di.sekitar.kita.

Wijaya, Surya Kusuma. "Masalah Infestasi Ektoparasit Pada Beberapa Jenis Burung Elang Di Habitat Eks-Situ." Unpublished Minithesis, Institut Pertanian Bogor, 2008. 